\title{
The Scope, Nature and Effect of EAC Law
}

\author{
John Eudes Ruhangisa
}

\subsection{Introduction}

\subsubsection{The Aim}

This chapter examines the scope and origins of EAC law as well as its strength and validity with regards to the Partner States. It does so with a view to analyzing the relevance of EAC law within the integration process. The importance of law within a regional bloc cannot be overstated, as there cannot be meaningful integration without a solid regulatory framework to provide guidance to the process. Undoubtedly, EAC law is a regulatory framework envisaged by the Partner States to direct and control the integration process. However, having the law scribed on paper is one thing, whereas giving effect to the law is another. This chapter, in the spirit of studying this dichotomy, assesses the status and effect of EAC law bearing in mind the fact that EAC has all the characteristics of a supranational organization. ${ }^{1}$

\subsubsection{The Structure}

In this chapter we open the discussion by examining the various sources of EAC law as provided by the Treaty which is the principal partnership accord as well as the parent instrument of the Community. With this background the study in this chapter goes on to analyze the range within which EAC law exerts its operation. The influence and consequence of EAC law in the national legal order is then evaluated before we proceed to look into the hierarchical relation

* Hon. Justice Prof. John Eudes Ruhangisa, judge of the High Court of the United Republic of Tanzania and former registrar of the East African Court of Justice.

1 For more and detailed discussion on the supranational character of EAC see John Eudes Ruhangisa, "From Rules to Reality: Creating a Legal Community for the EAC", A Key Note Address to the Second LEAC Conference on East African Integration Through law, organized by Leiden University in Collaboration with the East African Court of Justice, Held at EAC Headquarters, Arusha, Tanzania 5th May, 2016. See also Mbembe Binda, "Good Governance and Foreign Direct Investment: A Legal Contribution to a Balanced Economic Development in the East African Community", PhD Thesis, Utrecht University, The Netherland, 25th August 2015, at page 89 . 
of this law vis-à-vis national law. The chapter will conclude with a discussion on how EAC law relates to other regional and international law.

\subsection{Sources of EAC Law}

In order to explain the scope of EAC law it is important to first consider its sources. Each country or region has its own sources of law, which largely influence its legal system. The most common sources of law are Constitutions, Parliamentary legislation (statutes), judicial decisions, treaties, protocols and circulars issued by various policy organs. In the EAC regime, the sources of law are: the Treaty for the Establishment of the East African Community (the Treaty) which came into force on 7 th July 2000, following its ratification by the Partner States; Acts of the East African Legislative Assembly; decisions of the East African Court of Justice; Protocols; and formal directives and decisions of the policy organs of the Community. ${ }^{2}$

Within the EAC framework, the Treaty is the main source of Community law and it outlines the areas of cooperation on which the Partner States of the Community have agreed to cooperate. Under the Treaty it is agreed that, with a view to strengthening their cooperation, the Partner States are resolved to adhere to the fundamental and operational principles that shall govern the achievement of the objectives set out in the Treaty and to the principles of international law governing relationships between sovereign states. In this regard, the relevant provisions of the Treaty are: Article 5 on the Objectives of the Community; Article 6 on the Fundamental Principles of the Community; Article 7 on the Operational Principles of the Community; and Article 8 on the general undertaking as to implementation. For their mutual benefit, Partner States have agreed to cooperate in the following fields: political, economic, social, cultural, research, technology, defense, security, and legal and judicial affairs.

In modern democracies, the legislative function of the State is a preserve of the legislature (Parliament). This power is normally enshrined in the Constitution, which is the mother of all laws in a particular state. ${ }^{3}$ In the EAC, the Treaty regulates the powers and functions of the organs and institutions

2 According to the East African Community structure the policy organs of the Community are mainly two: the Summit of Heads of State and the Council of Ministers.

3 For example Article 64 (1) of the Constitution of the United Republic of Tanzania, 1977 which provides that "legislative powers in relation to all Union matters and also in relation to all other matters concerning mainland Tanzania is hereby vested in Parliament". Also Article 
of the Community in the same way that Constitutions regulate the affairs of states. Article 49 (1) of the Treaty vests the lawmaking function in the East African Legislative Assembly (the Assembly) as it provides that "The Assembly shall be the legislative organ of the Community."4 The Assembly plays its legislative role in the Community by passing Bills and having them assented to by the Head of States in the Summit. The Bills that have been duly passed and assented to are styled as Acts of the Community and are published in the East African Community Gazette.

However, under common law tradition, in the course of performing their duties, other state organs such as the judiciary can make law as well. Judges are not supposed to make laws as their duty is to interpret it, but through statutory interpretation a judge can make law. This is where the saying " $[j]$ udges make law" derives its origin. 5 The legal systems in the United Kingdom are based largely on judge-made law. Judge-made law is law developed through decisions by judges in the course of deciding cases brought before them. This is what is famously called "common law" or case-law. Although after the 17th Century new laws and law reforms in England have increasingly been brought about through Acts of Parliament, usually inspired by policies of the Government of the day, the development of case law still remains an important source of law. A statement of law made by a judge in a case can become binding on later judges and can in this way become the law for everyone to follow. ${ }^{6}$

The legal systems of the three founding countries of the EAC, ${ }^{7}$ which incidentally were under British colonial control, are Common law. It is this background that not only influenced their respective Constitutions, but also the Treaty and the respect they give to the binding decisions of the East African Court of Justice (EACJ).

The EACJ is the judicial body of the Community whose role, under Article 23 of the Treaty, is to ensure adherence to law in the interpretation and application of and compliance with the Treaty. The EACJ has exercised its mandate of interpretation under Article 27 of the Treaty by hearing and determining

94 (1) of the Kenya Constitution provides that "[t]he legislative authority of the Republic is derived from the people and, at the national level, is vested in and exercised by Parliament."

4 Article 49 (1) of the Treaty, Ibid.

5 Frederick Schauer, Do Cases Make Bad Law?, 73 U. Chi. L. Rev. 883 (2006). "It is thus no longer especially controversial to insist that common law judges make law."

6 Jan Komárek, Judicial Lawmaking and Precedent in Supreme Courts, (LSE Law, Society and Economy Working Papers 4/2011), http://ssrn.com/abstract=1793219.

7 The Republic of Kenya, the Republic of Uganda and the United Republic of Tanzania. The Republic of Burundi and the Republic of Rwanda acceded to the Treaty on 18th June 2007 and became full members on 1st July 2007. 
cases relating to infringement and contravention of the Treaty. Under Article 36 of the Treaty, the EACJ gives advisory opinions regarding questions of law arising from the Treaty which affect the Community. The EACJ also has jurisdiction under Article 32 of the Treaty to hear and determine any matter arising from an arbitration clause contained in a contract or agreement which confers such jurisdiction to which the Community or any of its institutions is a party or; arising from a dispute between the Partner States regarding the Treaty if the dispute is submitted to it under a special agreement between the Partner States concerned; or arising from an arbitration clause contained in a commercial contract or agreement in which the parties have conferred jurisdiction to it. The Court can also hear and give preliminary rulings on matters referred to it by the national courts or tribunals of a Partner State concerning interpretation or application of the provisions of the Treaty or the validity of the regulations, directives, decisions or actions of the Community. Invariably the judges of the EACJ through judicial pronouncements have also made laws in the course of interpreting the Articles of the Treaty and developing regional jurisprudence.

One example is the landmark case of Callist Andrew Mwatella \& 2 Others vs. EAC. ${ }^{8}$ In this historic ${ }^{9}$ case the applicants challenged the legality of the actions of the Council of Ministers and the Secretariat in assuming control over Assembly-led Bills. The Council had purported to withdraw four Private Members' Bills from the Assembly. The application before the Court questioned the right of the Council to delay the presentation of the Bills to the House. It also challenged the validity of the meeting of the Sectoral Council on Legal and Judicial Affairs (the Sectoral Council) held on 13th to 16th September 2005 and the decisions taken by it to write to the Speaker attempting to withdraw the Bills pending before the Assembly, including the recommendation to legalize decisions through Protocols not through Community Acts. The application sought an order by the Court that the report of the Sectoral Council meeting held on 13th to 16th September 2005 was null and void ab initio and requested the Court to find that all decisions, directives and actions contained in or based on it were null and void.

The Court found that the Sectoral Council on Legal and Judicial Affairs was not constituted per Treaty, in particular Article 14 which provided that the Council of Ministers shall "establish from among its members" only Sectoral Councils and that Sectoral Council members were restricted to "Ministers" as defined by the EAC Treaty. The Court found that Kenya and Tanzania were

8 Reference No. 1 of 2005.

9 It is a historic case in the sense that it was the first ever case to be filed in the Registry of the Court since 2001 when the Court was inaugurated. 
represented by non-ministers (including Attorney Generals) at the disputed meeting of 13th to 16th September 2005 and therefore the meeting was not properly constituted and did not amount to a lawful Sectoral Council meeting. In this regard, its decision regarding the two Bills was ipso facto invalid. However, the Court employed a prospective annulment principle as opposed to retrospective annulment in order not to take the Community back to square one on matters that the improperly constituted meeting had already decided. It was this particular decision of the Court that led to an amendment of the Treaty thereby validating participation of Attorney Generals in the Sectoral Council for Legal and Judicial Affairs. ${ }^{10}$

On another issue the Court found that under Article 59 (1) any Member of the Assembly may introduce a Bill. The Council does not have exclusive legislative initiative to introduce Bills in the Assembly. It held that the Assembly owns all Bills once tabled in the Assembly, whether they came initially by way of Private Members' Bills or Community Bills. As such, permission of the Assembly would be required for withdrawal of any Bill. Such approval must be sought and obtained through a motion passed by the Assembly and could only be withdrawn by the member from whom it originated. In this case the Council of Ministers was not the originator of the Bill. Thus, the Bill could not be withdrawn by the Council of Ministers as purportedly done. All the Council could do was to delay the debate.

As regards to the relationship between the Council and the Assembly, the Court found that each has its own enumerated areas of competency." It held that the Assembly is a creature of the Treaty as are the other Organs of the Community and its competencies lie only with matters conferred upon it by the Treaty, as is the case with all other Community Organs. In this regard, the Assembly could only legislate on matters on which the Partner States had surrendered sovereignty to the EAC.

By interpreting these Articles of the Treaty, the Court dutifully discharged its major function under the Treaty and provided guidance for future operations of the affairs of the Community Organs. The Court boldly told the Ministers and the Attorney Generals that they had overstepped their boundaries and that this was not acceptable in the realm of integration, where institutions are created and given specific mandates to facilitate the integration agenda.

10 Article 13 of the Treaty for the Establishment of the East African Community was subsequently amended to recognize the Attorneys General as Members of the Council by adding sub article (c).

Article 14 (3) (c) and Article 16. 
Moreover, the Court, in order not to cripple the activities of the Community, invoked the doctrine of prospective annulment. ${ }^{12}$

The EACJ has also played its interpretative role in the case of Attorney General of the Republic of Kenya vs. Independent Medical Legal Unit $t^{13}$ where the disputed issue among the parties regarded the interpretation of Article 30(2) of the Treaty. The raised issue was whether Article 30(2) of the Treaty, which provides a time limitation of two months, can be extended where there is a "continuous violation of human rights." The Appellate Division held that the Treaty does not grant the EACJ any express or implied jurisdiction to extend the time limit of two months.

Other cases where the Court has performed its interpretative role and developed the Community jurisprudence include Christopher Mtikila vs. The Attorney General of the United Republic of Tanzania and the Secretary General of the East African Community; ${ }^{14}$ Prof Peter Anyang' Nyong'o \& others vs. AG of Kenya \& 5 Others, ${ }^{15}$ and East African Law Society and 4 Others vs. Attorney General of Kenya and Others. ${ }^{16}$

The Council of Ministers is the policy organ of the Community. The role of the Council is to make regulations, issue directives, take decisions, make recommendations and give opinions which are binding on the Partner States; on all organs and institutions of the Community other than the Summit; the Court and the Assembly within their jurisdictions; and on those to whom they may under the Treaty be addressed. ${ }^{17}$ Thus, the Council also plays a law-making function within the Community.

If we were to rank the sources of EAC law hierarchically, there is no doubt that the Treaty leads in this arrangement as it specially presents itself in the integration process the way national constitutions lead in creating the rest of the laws in the respective countries. Likewise, in any regional organization it is the treaty that stands on top of the legal order as a groundnorm from which all laws derive their strength and origin. Protocols, being creatures of the Treaty, come next in the lineage of sources of law in the EAC. However, for ease of enforceability, and to give them effect, the contents and spirit of the protocols have to be translated into law by the Assembly through the legislative process. Likewise, the decisions or directives of the Council of Ministers or of

\footnotetext{
12 Reference No. 1 of 2005.

13 Appeal No. 1 of 2011.

14 Reference No. 2 of 2007.

15 Reference No. 1 of 2006.

16 Reference No. 3 of 2007.

17 Article $14(3)(d)$ and Article 16 of the Treaty.
} 
other policy organs of the Community have to be translated into law in order to give them a binding effect and make them enforceable in the court of law.

In any case, a Council decision cannot legally contravene the legislation of the Assembly. If it does, wittingly or unwittingly, such decision of the Council shall be ultra vires the law and therefore void to the extent it contravenes that legislation. Could this be one of the reasons for the Council of Ministers' reluctance or very slow pace in presenting Bills that translate the protocols into Acts of the Assembly? For quite some time the Council of Ministers has been uncomfortable with demands and even attempts to translate the protocols into law. This prompted three members of the Assembly to seek the Court's intervention in the case of Callist Andrew Mwatella \& 2 others vs. EAC (Supra), where the Council decided to hold the Private Members' Bills ${ }^{18}$ that were sent to the Council for input. The Council was of the strong view that there was no need for specific legislation in those areas since the relevant protocols, the Treaty and Council decisions were adequate.

It is important to note that in 2013 the Council of Ministers proposed an amendment to the Treaty which would somewhat ensure its full control of the Assembly. This was at the instance of one Partner State which was not happy with a Private Members' Bill that sailed through to become an Act of the Assembly. It failed however, when the remaining three Partner States declined to support the proposal to amend the Treaty. The proposed amendment intended to remove the part of Article 59 that states as follows: "subject to the rules of procedure of the Assembly, any member may propose any motion or introduce any Bill in the Assembly."19 If the said proposed amendment sailed through, it would have substantially reduced the amount of legislation for passing through the Assembly, as most Bills are proposed by private members.

It is legitimate to state that there has been a running tension between the Council of Ministers and the Assembly, with the former heavily relying on protocols and Summit directives to move forward key aspects of the integration agenda, something viewed as a slight by the Assembly. This is particularly seen in the relationships between Protocols and Acts, whose contents can overlap. ${ }^{20}$

18 The East African Community Trade Negotiation Bill, The East African Community Budget Bill, The East African Community Immunities and Privileges Bill, and The Inter-University Council for East Africa Bill.

19 At the 25th Meeting of the Council of Ministers held in Bujumbura in August, Tanzania proposed that article 59 of the Treaty be amended to remove the part that states that "subject to the rules of procedure of the Assembly, any member may propose any motion or introduce any Bill in the Assembly."

EAC Regulatory Capacity Review. 
The Assembly is not in favour of protocols, because they limit its flexibility, while the Council prefers protocols, which are its own creation and within its control.

\subsection{Scope of EAC Law}

The scope of EAC law mostly covers matters related to the adherence to, application of, and compliance with the Treaty. This means that EAC law restricts itself only to the areas of cooperation as identified and agreed upon by the Partner States and it is within these areas where EAC law takes precedence over similar laws of Partner States. The agreed areas of cooperation are: political, economic, social and cultural fields, research and technology, defence, security and legal and judicial affairs. ${ }^{21}$

Although the EAC Partner States have expressed, through the Treaty, their common desire of ceding some elements of their sovereignty to the EAC (a supranational organization), they still maintain a considerable degree of sovereignty. In this regard it is only in the identified areas of cooperation that they have relinquished some sovereignty as it is only in these areas that Partner States are under an obligation to harmonize their policies and laws. Likewise, it is only in these areas that the Assembly can legislate. This scenario introduces the pertinent question of when and where EAC law can be relied upon. This question has two limbs, "when" and "where". The answer to "when" is partly found in the discussion above but may also be personal. Legal persons (natural persons and fictitious persons such as corporations) may invoke EAC law at any time, if their rights under the Treaty have been infringed or violated by a Partner State or an institution of the Community. The Treaty clarifies this view by providing that "any person who is resident in a Partner State may refer for determination by the Court, the legality of any Act, regulation, directive, decision or action of a Partner State or an institution of the Community on the grounds that such Act, regulation, directive, decision or action is unlawful or is an infringement of the provisions of this Treaty."22

The answer to the second limb of the question, "where", is also answered by the Treaty in Articles 33 and 34. While the EACJ exercises jurisdiction over disputes that arise out of the Treaty, this jurisdiction is not exclusive to the EACJ; national courts also share part of this jurisdiction. The Treaty provides that except where jurisdiction is conferred on the Court by the Treaty, disputes

21 Article 5 (1) of the Treaty, op. cit.

22 Article 30 of the Treaty. 
to which the Community is a party shall not on that ground alone, be excluded from the jurisdiction of the national courts of the Partner States. ${ }^{23}$ This appears strange and contradictory when the same Treaty goes on to say that decisions of the EACJ on the interpretation and application of the Treaty shall have precedence over decisions of national courts on a similar matter. ${ }^{24}$

It is the role of the Court to ensure that rules are adhered to in the course of integrational pursuits, and that the rights of the citizens are respected across the region. For there to be consistency in the way integration issues are being handled, EACJ decisions on integration matters should prevail over national courts and other tribunals, per Article 33 (2), despite Article 33 (1) calling for national courts to share jurisdiction with EACJ on Community matters.

Furthermore, the EACJ's jurisdiction is circumscribed by other judicial mechanisms that have been introduced by subsequent Protocols to the Treaty. This can be seen in both the Customs Union Protocol and the Common Market Protocol. Article 41(2) of the Customs Union Protocol, which deals with dispute settlement, establishes committees to handle disputes arising out of the Protocol and gives these committees finality in determining such disputes. The Court is excluded and denied a role in the entire process except if a party challenges the decision of the Committee on grounds of fraud, lack of jurisdiction or other illegality. ${ }^{25}$

Again, under Article 54(2) of the Common Market Protocol, jurisdiction to entertain Common Market related disputes has mainly been given to national courts the EACJ is given a very limited role. The national courts are responsible for dealing with complaints by businesses and citizens to protect their rights under EAC regulations. However, as stated earlier, while the national courts are given first priority on matters concerning the enforcement of rights and freedoms arising out of the Common Market Protocol, Article 33(2) of the Treaty recognizes EACJ decisions on the interpretation of the Treaty and Community law as being superior to national court decisions on the same matter. This tendency of ousting the jurisdiction of the EACJ is not conducive to the integration agenda and has the effect of undermining the Court itself and hindering the development of uniform regional jurisprudence.

\footnotetext{
23 Article 33 (1) of the Treaty.

24 Article $33(2)$ of the Treaty.

25 Harold R. Nsekela, Overview of the East African Court of Justice, A Paper Presented During the Sensitisation Workshop on the Role of the EACJ in the EAC Integration, Imperial Royale Hotel, Kampala, Uganda, 1st-2nd November, 2011. See on the different situaiotn under EU law, where the CJEU has always claimed exclusive ultimate jurisdiction, Eu Chapter 4.
} 
Upon the opportunity to make a judicial pronouncement on the systematic erosion of its jurisdiction, the EACJ, while answering the issue whether it lacks jurisdiction over disputes arising out of the implementation of the Customs Union and the Common Market Protocols and after examining the impugned Articles of the Protocols, tried to find a way of guarding its jurisdiction by making the following finding:

... we do not find, within the Customs Union and the Common Market Protocols, a provision that confers jurisdiction to resolve disputes arising from the interpretation of provisions of both Protocols either to an organ of a Partner State or of the Community, save this Court. ${ }^{26}$

The Court concluded that it has jurisdiction over disputes arising out of the interpretation and application of the Treaty which, for re-emphasis, includes the Annexes and Protocols thereto. However, the Court did not take time to either expound on the relevance of the impugned Articles of the Protocols or explain the intention of the Partner States in including the provisions which appear to suggest that the Court does not have jurisdiction over these matters. This issue is exemplified when the said impugned Articles of the Protocols are read together with a proviso to Article $27(1)$ of the Treaty which states:

Provided that the Court's jurisdiction to interpret under this paragraph shall not include the application of any such interpretation to jurisdiction conferred by the Treaty on organs of Partner States.

Throughout the hearing of the case the Counsel to the Community who represented the Respondent kept the Court under constant reminder of the intention of those who framed the impugned Articles of the Protocols, the exercise he coordinated, as being to oust the jurisdiction of the Court in these matters.

The submission by the Counsel to the Community about the Court not having jurisdiction over such matters had been the position consistently taken by the Partner States. This view can be found in the submission by Mr. Amos Wako, the then Attorney General of the Republic of Kenya, during the hearing of an Application for temporary injunction in the famous Anyang' Nyong'o case $^{27}$ where he said:

26 Case of East African Law Society v. The Secretary General of the East African Community, Reference No. 1 of 2011, at pg 23 of the Judgment.

27 Peter Anyang' Nyong'o and 10 Others $v$. The Attorney General of the Republic of Kenya and 5 Others, Reference No. 1 of 2002. 
... Since you have an Article in the treaty which is specific to that issue, Article $5^{2}$ then you have no jurisdiction. This is because the matter for deciding on the validity of election is a matter for the national courts and not this court [EACJ]. In other words, at the stage in which we are today, with your limited jurisdiction, you should not wittingly or unwittingly, assume jurisdiction on matters on which the Treaty itself has said should be determined by the national courts. ${ }^{28}$

When the Court in its ruling rejected the Attorney General's argument on this, the Treaty was immediately amended to mark the Partner States' seriousness and a proviso to Article 27 (1) was added. The added amendment basically reflected the above Attorney General's views. Considering this background, it is likely that the purpose for including the impugned controversial dispute settlement provisions in the two Protocols was to oust the jurisdiction of the Court, an outcome which would arguably be detrimental to integration. ${ }^{29}$

\subsection{The Effect of EAC Law in the National Legal Order}

The EAC Treaty came into force upon ratification by all three founding Partner States and upon the Partner States successfully depositing the instruments of ratification with the Secretary General. ${ }^{30}$ Once this was completed, the Treaty became part of the law of the land but it had no special position within the individual Partner States' legal framework until it was formally accepted by their respective Parliaments. The EAC Partner States have dualist as opposed to monist systems regarding the relationship between their respective national law and international law or other regional law. In monist States, international or regional law does not require to be translated into national law, but it is simply incorporated and has an automatic effect in national or domestic systems. On the contrary, dualist States, the category to which the EAC Partner States belong, accentuate the difference between national and international law, and

28 Pg 65 of the typed court proceedings of 24/11/2006 in the case of Peter Anyang' Nyong'o and 10 Others $v$. The Attorney General of the Republic of Kenya and 5 Others, Reference No. 1 of 2002. [Emphasis added].

29 Compare in this regards also Opinion 2/13 on the draft agreement providing for the accession of the European Union to the Convention for the Protection of Human Rights and Fundamental Freedoms ECLI:EU:C:2014:2454, and the rules of the jurisdiction of the CJEU discussed in EU Chapter 4.

30 Article $15^{2}$ of the Treaty. 
require the translation of international law such as Treaties and Protocols into national law by way of ratification or domestication. Therefore, in order to give effect to the Treaty, the Partner States had to incorporate it into their national legal systems by way of ratification/domestication. ${ }^{31}$ This incorporation was achieved by the passing of domestic legislation that gave effect to the Treaty within each national legal system. ${ }^{32}$ This is as provided by Article 8(2) of the Treaty which stipulates that:

Each Partner State shall, within twelve months from the date of signing this Treaty, secure enactment and the effective implementation of such legislation as is necessary to give effect to the Treaty, and in particular-

(a) to confer upon the Community the legal capacity and personality required for the performance of its functions; and

(b) to confer upon the legislation, regulations and directives of the Community and its institutions as provided for in this Treaty the force of law within its territory. ${ }^{33}$

In accordance with this Treaty provision, each Partner State enacted a specific law to give effect to the Treaty within the domestic legal order. In the case of Uganda for example, this law is the East African Community Act of 2002 (EAC Act). The EAC Act gives the force of law in Uganda to the Treaty ${ }^{34}$ since the Treaty provisions are also part of the law of the land ${ }^{35}$ and can be enforced and allowed in Uganda. ${ }^{36}$ In the case of the United Republic of Tanzania, through its Legislature the law was enacted to domesticate the Treaty. ${ }^{37}$ It is this particular Act, No. 4 of 2001 that provides for giving effect to the provisions of

31 Articles 152 Ibid.

32 For Tanzania see The Treaty for the Establishment of the East African Community Act, 2001 (Act No. 4 of 2001 / Cap 411). For Uganda see East African Community Act, 2002, for Kenya see The Treaty Establishing the East African Community Act (No. 2 of 2000), for Rwanda see Law No. 29/2007 of 27/06/2007, and for Burundi the information that was obtained during research was that Burundi has no specific law in place domesticating the treaty as the country ascribes to the principle of Monism. Accordingly when EAC Treaty was ratified it became part and parcel of the laws of Burundi. As such there was no need for enacting another law domesticating EAC Treaty. Article 8 (2) of the Treaty, op. cit.

34 Section 3 (1) of East African Community Act, 2002 (Uganda).

35 Dora Byamukama, "The EAC Treaty has the force of law in Uganda", op. cit.

36 Section $3(2)$ of the East African Community Act, op. cit.

37 The Treaty for the Establishment of the East African Community Act, 2001 (Act No. 4 of 2001 / Cap 411). 
the Treaty for the Establishment of the East African Community and for connected purposes. This law applies to Tanzania Mainland as well as to Tanzania Zanzibar. ${ }^{38}$

In my view, the directive of Article 8(2) of the Treaty in relation to EAC law goes against direct effect. This is a major difference with Eu law, and perhaps the breeding ground for problems in the future as integration gains momentum. ${ }^{39}$

Arguably this legal requirement for domestication of the Treaty and the Protocols ${ }^{40}$ represents an escape clause for direct effect of international agreements as commonly understood under Public International Law. However, there is no such requirement for ratification of EAC laws enacted by the Assembly in exercise of its legislative powers. EAC laws, therefore, take immediate and automatic effect in the Partner States after being signed by the Head of States of the Partner States. In other words, EAC laws have direct effect and take precedence over similar laws in the Partner States. ${ }^{41}$

The effect of EAC Protocols is unclear. Arguably the domestication of the Treaty by the Partner States was by extension and by necessary implication the domestication of the Protocols thereto as the Protocols form an integral part of the Treaty. ${ }^{42}$ The ambivalence here is whether subsequent Protocols signed by the EAC would by effect of the domesticated Treaty be automatically binding on the Partner States without being ratified first. The Treaty makes the situation even more confusing when it categorically provides that each Protocol shall be subject to signature and ratification by the parties thereto. ${ }^{43}$

Within the EAC structure, the Assembly is the only Organ mandated to enact the laws for the Community. ${ }^{44}$ By the term "laws", we refer to Acts of the Assembly as opposed to other legal instruments ${ }^{45}$ originating outside the Assembly framework. Invariably the Assembly passes legislation the way National Parliaments legislate for the respective Partner States. However,

\section{Section $1(2)$ Ibid.}

39 Compare in this regard also EU Chapter 4 on the conditions for direct effect of EU law. under EU law, moreover, this direct effect depends on EU law itself, not on the national laws transposing EU law.

According to Article 151 (4) of the Treaty, Protocols are integral parts of the Treaty.

41 They can be compared in that sense to EU Regulations.

42 Article 151 (4) of the Treaty, Ibid.

43 Article 151 (3), Ibid.

44 Article 49 (1) of the Treaty, Ibid.

45 Other legal instruments include for example Protocols, Memorandum of Understanding, Regulations and Rules. Regulations and Rules are subsidiary legislation made by various authorities which derive the authority to do so from the Treaty, Protocol or any Principal Act made by EALA. 
according to the Treaty as earlier highlighted, the legislation to domesticate the Treaty, effectively conferred upon the Community legislation, regulations and directives, the force of law within its territory such that once passed as an Act of the Community then that law so enacted by the Assembly should also become a law domesticated, as provided under Article 8(2) (b) highlighted above.

Accordingly, under Article 8 (2) (b) any Community law enacted by the Assembly, as well as the regulations and directives of the organs of the Community have a direct effect such that there is no further ratification or redomestication of any EAC law required subsequent to the domestication of the Treaty by the Partner States. One such example is the Customs Management Act, 2004 which was enacted by the Assembly to replace the respective customs laws of the Partner States. ${ }^{46}$ This Community law did not undergo any ratification procedure in the Partner States.

The EACJ decisions on EAC matters do not only bind the Community and its organs but also the Partner States and their respective institutions including national courts. The EACJ has to remain steadfast in the discharge of its functions as although under the Treaty the Partner States have undertaken to maintain the rule of law this does not necessarily translate into practice. The Partner States have demonstrated the lack of it especially when the Court ruled in the case of Anyang' Nyongo' in 2006 temporarily halting the business of the Assembly. The Partner States immediately embarked on a process of amending the Treaty which was also another subject of a Reference by the East African Law Society. ${ }^{47}$ The Court stood its ground and even in the subsequent judgments in the case of Anyang' Nyong'o and that of the East African Law Society it declared the process of amending the Treaty and some provisions introduced in the Treaty as infringing the same Treaty.

The Partner States have under Article 38 of the Treaty undertaken to accept and implement the judgments of the EACJ. Under Article 33 of the Treaty, decisions of the Court on interpretation and application of the Treaty have precedence over decisions of national courts on similar matters. This specific Article has implications for the national Courts as the decisions of the EACJ can therefore be used as precedents in the national courts.

46 Other such laws include: The East African Community standardization, Quality Assurance, Metrology and testing Act, 2006; The East African Community Competition Act, 2006; The Lake Victoria Transport Act, 2007. 
Although the EACJ does not have execution mechanisms whereby it can compel the Partner State to comply with its decisions, there has not been any instance where the Partner States have declined to comply with the Court's decisions. This can be evidenced from the cases of James Katabazi \& 21 Others vs the Attorney General of the Republic of Uganda and the Secretary General of the East African Community, ${ }^{48}$ Plaxeda Rugumba vs the Attorney General of the Republic of Rwanda, ${ }^{49}$ Prof Anyang' Nyongo \& 10 Others vs the Attorney General of the Republic of Kenya and 5 Others. ${ }^{50}$ In these cases the Court made declarations that the acts of the Partner States were in contravention of the Articles of the Treaty with which the Partner States complied by taking steps to correct or rectify the Act, regulations, directives, decisions or actions that had infringed the Articles of the Treaty. A good example is the case of Anyang' Nyongo' where the Republic of Kenya had to review its rules of elections of Kenyan representatives to the Assembly in order to comply with Article 50 of the Treaty. Moreover, in the case of Katabazi suspects of terrorism were released by the state security agent which had initiated court martial criminal proceedings against them notwithstanding the fact that they were civilians and during which the suspects were denied bail and legal representation.

The effect of the EACJ not having execution mechanisms of its own is that under Article 44 of the Treaty it will depend on the process of execution in the Partner States regarding matters of pecuniary nature. However, where execution regards matters where the Court has made declaratory decisions then it will rely on the goodwill of the Partner States to implement or comply with the decisions of the Court.

\subsection{The Hierarchy between EAC Law and National Law}

Essentially, a discussion on the hierarchy between EAC law and national law is a discussion on which of the two sets of law is superior to the other if they were to be placed on a ladder to determine the order of precedence. This goes with the examination on the usefulness of EAC law to the people living in the Partner States.

In order to complement Article 8 (2) (b), the Treaty goes on to state categorically that Community organs, institutions and laws shall take precedence

\footnotetext{
$48 \quad$ Reference No. 1 of 2007.

49 Reference No. 8 of 2010.

$5^{0}$ Reference No. 1 of 2006, This case is reported in EALS Law Digest, 2005-2011, pp. 173-195, published by EALS with leave of EACJ.
} 
over similar national ones on matters pertaining to the implementation of the Treaty. Further the Partner States are under a general obligation to make the necessary legal instruments to confer precedence of Community organs, institutions and laws over similar national ones. It is this particular character of precedence of Community institutions and Community laws that makes the EAC a supranational organization as opposed to an intergovernmental one. ${ }^{51}$ This, in essence, means that if there is a Community law on Customs Management, for example, like the East African Community Customs Management Act, 2004 this law automatically takes precedence over similar national laws on matters pertaining to the Treaty. ${ }^{52}$ This view is supported by the essence of Section 3 of the East African Community Customs Management Act, 2004 which provides that "The Directorate of Customs as established by the Council under the Treaty shall be responsible for the initiation of policies customs and related trade matters in the Community and coordination of such policies in the Partner States".

The hierarchy of EAC Law over national law can also be found in Article 33 of the Treaty read together with Article 27 on Jurisdiction of the Court and Article 34 according to which national courts may refer matters on issues of interpretation of the Treaty for a preliminary ruling by the EACJ. This is one of the rare opportunities where national courts, at all levels, are given a chance to interact with an international court through litigation. When faced with a case requiring the application or the interpretation of the Treaty or any other EAC law, the national courts are required to refer the matter to the EACJ for preliminary ruling. ${ }^{53}$ Unlike other regional and international courts there is no requirement under the EAC Treaty that a party must exhaust local remedies before coming to the EACJ. A party may file a case with the EACJ in respect of a violation or infringement of an Article without having to exhaust local remedies as long as he/she is resident in a Partner State. ${ }^{54}$

Under Article 33(2) of the Treaty, decisions of the EACJ on matters of interpretation and application of the Treaty have precedence over decisions of the national courts on similar matters. Article 34 of the Treaty also provides

$5^{1}$ It is interesting to note that whereas the Treaty recognizes East African Community as a supranational organization, the EAC Secretariat and the Partner States degrade it to the status of being an intergovernmental organization, and this is the meaning of EAC as posted on the EAC web site. Compare in this regard also the central importance of the supremacy of EU law for the nature and effectiveness of the EU, as described in $\mathrm{EU}$ Chapter 4 .

$5^{2}$ See Dora Byamukama, "The EAC Treaty has the force of law in Uganda", New Vision News Paper, Kampala, Uganda, 25th November, 2015.

53 Article 34 of the Treaty, op. cit.

54 Section 30 (1) of the Treaty, op. cit. 
that where a question is raised before any court or tribunal of a Partner State concerning the interpretation or application of the provisions of the Treaty or validity of the regulations, directives, decisions or actions of the Community, that Court or tribunal shall, if it considers that a ruling on the question is necessary to enable it to give judgment, request the Court to give a preliminary ruling on the question. The implementation of this provision requires the national judge before referring the issue to the EACJ to first satisfy himself that the following two conditions are fulfilled: 55

1) A question concerning the interpretation or application of the Treaty or a question concerning the validity of the regulations, directives, decisions or actions of the Community must be raised in a case before him;

2) A ruling on the question must be necessary to enable the national judge to give judgment in the particular case.

With regards to the first condition, namely that "a question of Treaty interpretation must be raised", the national court is solely entitled to appreciate whether or not a particular case raises a question of interpretation or application of the Treaty or a question concerning the validity of the regulations, directives, decisions or actions of the Community. The answer by the EACJ to the question raised by national courts in the reference for preliminary ruling is binding on the court that made the reference and on other national courts when subsequently faced with a similar issue. The Treaty is silent as to who should raise this question. Arguably, the question could be raised by any party to the case before the national judge or by the judge himself/herself.

However, it follows from the second condition that any such question does not necessarily need to be referred to the EACJ for a preliminary ruling. The question must be necessary in order for the national court to give its judgment. This of course leaves the national court very wide discretion to ascertain whether a decision on a question of Community law is necessary to enable it to give its judgment. In the exercise of this discretion, the national courts must be guided by a number of principles which are not provided for in the Treaty. ${ }^{56}$

55 See for further details on this procedure under EAC and EU law Chapter 8 and EU Chapter 8.

56 Harold R. Nsekela, "Cooperation between the East African Court of Justice and the national courts of Partner States", A Paper presented during the United Republic of Tanzania Judges Conference, Arusha, Tanzania, 31 August, 2009. 
To fill this void the EACJ formulated and published guidelines for national judges wishing to refer questions to the EACJ for preliminary ruling. ${ }^{57}$

The issue of hierarchy between EAC law and national law was discussed in a reference for preliminary ruling to the EACJ made by the High Court of Uganda under Article 34 of the Treaty in the proceedings involving The Attorney General of the Republic of Uganda and Tom Kyahurwenda. ${ }^{58}$ The High Court of Uganda had referred for a preliminary ruling on two questions:

(a) Whether the provisions of Articles 6, 7, 8 and 123 read together with Articles 27 and 33 of the Treaty are justiciable in the national courts of Partner States; and

(b) Whether the provisions of Articles 6, 7, 8 and 123 read together with Articles 27 and 33 of the Treaty are self-executing and confer sufficient legal authority on the national courts of the Partner States to entertain matters relating to Treaty violations and to award compensation and/or damages as against a Partner State.

At paragraphs $5^{0}$ and $5^{1}$ of its ruling the Court stated as follows:

50. The Court holds that by resorting to the use of the word "shall" in Article 34 and having regard to the raison d'etre of the preliminary ruling procedure expounded above, it was the intent and purpose of the framers of the Treaty to grant this Court the exclusive jurisdiction to entertain matters concerning interpretation of the Treaty and annulment of Community Acts.

51. The Court deems it important to distinguish the application of the Treaty from interpretation of the same as found in Article 34. Whereas, as we held above, interpretation is the preserve of this Court, the same is not necessarily the case for the application of the Treaty by the national courts to cases before them. It would defeat the purpose of preliminary reference mechanism if the Court's interpretation of Article 34 of the Treaty extended to "application of treaty provisions". The purpose for the mechanism is for the national courts to seek Application before the High Court of the Republic of Uganda ("the High Court") arising from Civil Suit No. 298 of 2012 between Tom Kyahurwenda and The Attorney General of Uganda. The High Court stayed the proceedings pending the preliminary ruling of the East African Court of Justice ("the Court"). 
interpretation of the Treaty provisions in order that they may then apply them to a case at hand. Hence, to interpret Article 34 as requiring "application of the Treaty provision" to be excluded from the purview of national courts would "lead to a result which is manifestly absurd or unreasonable". In this regard, Article $32(b)$ of the Vienna Convention on the Law of Treaties cited above acknowledges an absurdity exception to the literal interpretation of any Treaty.

52. The national courts seek interpretation from this Court in order to be empowered to apply the Treaty provisions to the facts of the case(s) before them.

In conclusion the Court held that:

(a) Article 34 of the Treaty for the Establishment of the East African Community grants this Court exclusive jurisdiction to interpret the Treaty and to invalidate Community Acts.

(b) National courts and tribunals are entitled to entertain matters involving the violation of the Treaty and the application of the provisions of the Treaty within the context of Articles 33 and 34.

(c) Decisions of this Court in the interpretation of the Treaty take precedence over decisions of the national courts and tribunals on similar matters.

(d) Articles 6, 7 and 8 of the Treaty are justiciable before the national courts and tribunals of the Partner States.

(e) While they remain inoperative, Paragraphs 2, 3 and 4 of Article 123 of the Treaty are not justiciable both before this Court and before the national courts and tribunals.

In East African Law Society vs the Secretary General of the East African Community, Reference No. 1 of 2011 the Court held that:

As Partner States, by virtue of their being the main users of the Common Market Protocol on a daily basis, it would be absurd and impractical if their national courts had no jurisdiction over disputes arising out of implementation if it did not provide for right of individuals to invoke it before national courts.

From the above explanation and cases, it appears that national courts can entertain matters related to Community law in respect of application of the Treaty but when it comes to interpretation of the Treaty it is the sole jurisdiction 
of the EACJ. With regard to Article 33(2) which provides that the decisions of the Court on the interpretation and application of the Treaty shall have precedence over decisions of national courts on a similar matter, the court opined at paragraph 60 that reading the Article together with Articles 27 and 34 it would be that the framers of the Treaty envisaged a situation where it is possible to contract out of the general norm of the EACJ having sole jurisdiction as to interpretation; and to give instead, concurrent jurisdiction of interpretation on a given subject matter to both the Court and the national courts. In such case the interpretation of the EACJ takes precedence.

It also appears that the Court has concurrent jurisdiction with the national courts. This matter was discussed in two cases where the Court was of the view that the Treaty needs to be amended to rectify this. In the case of East African Law Society and 4 Others vs the Attorney General of Kenya and 3 Others ${ }^{59}$ the Court observed the need to amend the new proviso that was introduced in Article 27(1) on Jurisdiction of the Court that states "Provided that the Court's jurisdiction to interpret under this paragraph shall not include the application of any such interpretation to jurisdiction conferred by the Treaty on organs of Partner State". This proviso should also be read together with Article 30(3) that provides "The Court shall have no jurisdiction under this Article where an Act, regulation, directive, decision or action has been reserved under this Treaty to an institution of a Partner State". It should also be read together with 33(1) "Except where jurisdiction is conferred on the Court by this Treaty, disputes to which the Community is a party shall not on that ground alone, be excluded from the jurisdiction of the national court of the Partner States". The Court has reiterated in several decisions as those mentioned hereinabove expressed the need to amend the Treaty in order to clear the confusion.

\subsection{The Relationship between EAC Law and Other Regional and International Law}

As indicated earlier in this work, the EAC Partner States have dualist as opposed to monist systems regarding the relationship between their respective national law and international or regional law. This means that international law has to be national law as well otherwise it will not be considered as law in dualist systems and judges cannot apply it nor can citizens rely on it. 
As the EAC is not, as of yet, considered to be a state, any international or other regional laws are of no effect to the EAC as a Community but only bind the individual Partner States that subscribe to that particular international law. In that case the usual dualist state procedure has to be followed for such international or regional law to be applied in a particular Partner State where EAC law has direct effect.

Arguably, the only international law that the Treaty recognizes and adopts within the EAC legal framework is the African Charter on Human and Peoples Rights which is explicitly mentioned in Article 6 of the Treaty:

The fundamental principles that shall govern the achievement of the objectives of the Community by the Partner States shall include:

a) ...;

(b) $\ldots$;

(c) $\ldots$;

(d) good governance including adherence to the principles of democracy, the rule of law, accountability, transparency, social justice, equal opportunities, gender equality, as well as the recognition, promotion and protection of human and peoples rights in accordance with the provisions of the African Charter on Human and Peoples' Rights. ${ }^{60}$

While, the EACJ is not bound by decisions of other regional and national courts, such decisions are considered to be of persuasive authority. The EACJ has drawn a lot of inspiration from the revolutionary case law of the Court of Justice of the European Union (CJEU) which can be evidenced in many of its judgments where it has cited some of the cases of the CJEU. This shows that the EACJ recognizes the potential advantages of the European notions of autonomy and primacy of Community law. ${ }^{61}$ Other regional Courts such as the SADC Tribunal and the Comesa Court of Justice have also gained inspiration from the decisions of the EACJ when handling cases before them and vice versa.

Furthermore, in playing its role of interpretation of the EAC Treaty the Court has largely drawn inspiration from the Vienna Convention on of the Law of Treaties and from other sources of persuasive value.

6o Article 6 of the Treaty, op. cit.

61 See further on these concepts EU Chapter 4. 


\subsection{Conclusion}

The discussion in this chapter has examined the sources of EAC law, its scope and its supranational character. It has been pointed out that the supranational character of EAC law as envisaged under the Treaty to a large extent puts the Partner States in a very difficult situation for they are not wholly ready to cede a substantive part of their sovereignty. This creates a dichotomy in that Partner States still wish to maintain their full sovereignty whereas their commitments under the Treaty demand them to cede part of their sovereignty to a the Community. This is a paradoxical situation which Partner States find themselves in whenever they are called upon to propose Bills for legislation by the Assembly. As a result, Partner States prefer Protocols to Acts of the Assembly, the position that is vehemently opposed by the members of the Assembly who resort to tabling Private Members' Bills. 